DOI 10.18551/rjoas.2019-03.06

\title{
EXPRESSION OF HSP70 IN KOI HERPESVIRUS-INFECTED TILAPIA (OREOCHROMIS NILOTICUS)
}

\author{
Wahidi Budi Rianto \\ Postgraduate Program, Faculty of Fisheries and Marine Science, University of Brawijaya, \\ Indonesia
}

Yanuhar Uun, Fadjar Mohamad, Andayani Sri

Faculty of Fisheries and Marine Science, University of Brawijaya, Indonesia

*E-mail: wachidi vespa@yahoo.com

\begin{abstract}
Koi herpesvirus (KHV) not only can infect cyprinidae, but also infect other freshwater fishes. It causes KHV to spread widely throughout the world. Infection of KHV in fish has several symptoms and one of them is increased HSP70 expression. The purpose of this study is to detect HSP70 expression in KHV-infected tilapia. The study were carried out by qualitatively examining expression of HSP70 in the gill of tilapia, both normal tilapia and KHV-infected tilapia, and by detecting the tissue damage caused by KHV by means of histopathology. The results of this study show that HSP70 was detected in fish that were infected by KHV, while in control fish, HSP70 was not detected. This result indicates that tilapia infected by KHV experience an increase in HSP70 expression. Damage to the gill of tilapia is also one of the responses to KHV antigens in the host cell. Thus, this study presumed that KHV infection in tilapia is influenced by the expression of HSP70.
\end{abstract}

\section{KEY WORDS}

HSP70, KHV, Oreochromis niloticus, fish, infection.

Koi herpesvirus (KHV) is classified in the family of Herpesviridae (Hedrick et al. 2000; Yuasa et al. 2005). Although it has been named carp interstitial nephritis and gill necrosis virus (CNGV) (Hutoran et al. 2005), Waltzek et al. (2005) have provided facts that support the classification of KHP as herpesvirus and named it Cyprinid herpesvirus 3 (CyHV-3), following the nomenclature of other Cyprinid Herpesviruses, CyHV-1 (carp pox virus, fish papilloma) and CyHV-2 (goldfish hematopoietic necrosis virus).

Mass mortality of common carp due to KHV infection has been reported since 1997 in Germany (Bretzinger et al. 1999). Since then, KHV has spread rapidly throughout the continent (Haenen et al. 2004; Sano et al. 2004; Sunarto et al. 2004). Koi herpesvirus (KHV) also causes mass death of common carp, both in cultivation and in the wild (Garver et al. 2010). Rapid and widespread infection of KHV shows cross-continental dissemination of this pathogen. The international trade in koi carp is one of the biggest causes of KHV dissemination. Although KHV is not virulent and does not cause death in fish other than carp or cyprinidae, KHV can infect other freshwater fishes as well (Hedrick et al. 2000; Hedrick et al. 2006; Bergmann et al. 2010; Bergmann et al. 2016). In addition, KHV is also reported to be able to infect tilapia (Oreochromis niloticus), even though it does not show clinical symptoms or not even cause death (Suprapto \& Kartika, 2012; Wahidi, 2014).

Infection of KHV causes damage to cells within gill tissue in the form of necrosis, hyperplasia, and inter-lamellar fusion (Hedrick et al. 2000; Perelberg et al. 2003). Damage to the tissue of tilapia is a response to KHV antigens in host cells. Tissue damage within the gills is an indication of inflammation as a result of virus infiltration and activity in viral replication. Activity in viral replication is indicated by the formation of inclusion body. In general, inclusion body in KHV infection is found in gill, kidneys, liver, and brain (Perelberg et al. 2003; Taukhid et al. 2004). This is a response to the attack of antigens found in the host cell. In consequence, cellular response to antigen attacks result in tissue damage. One 
response to stress is in the form of Heat Shock Protein 70 (HSP70) induction. HSP70 is a group of stress proteins expressed by host cells to protect physiological tissue against environmental changes or antigens infection and maintain its condition (Yanuhar et al. 2015).

Moreover, increased expression of HSP70 is thought to be an indicator or biomarker for several viral infections, including herpesvirus (HSV1) (Santoro, 1994; Diaz-Latoud et al. 1997), denovirus type 5 (Mayer, 2005), vaccinia virus (Jindal \& Young, 1992), Whispovirus (white spot syndrome virus) (Lin et al. 2011). This study aims to determine the expression of HSP70 within the gills of KHV-infected tilapia, which is presumed to be the major portal of entry for KHV into the body of fish in its relation to cellular function of HSP70.

\section{MATERIALS AND METHODS OF RESEARCH}

Tilapia samples used in this study were obtained from traditional fish farming in AbarAbir Village, Bungah District, Gresik Regency, East Java, Indonesia. Samples of 20-to-30 tilapias were taken randomly in alive condition from each fishpond. For control fish, 10 tilapias of 7-10 cm were used. Furthermore, those tilapias were brought to the Fish Quarantine Laboratory for dissection under sterile condition. The dissected organs were taken for DNA extraction and histopathology examination.

Polymerase Chain Reaction (PCR) Testing:

DNA Extraction. $25 \mathrm{mg}$ of gills were crushed and homogenized in $180 \mu \mathrm{l}$ of AL buffer using a microtube and digested in $20 \mu \mathrm{l}$ Proteinase $\mathrm{K}$ at $560 \mathrm{C}$ for 10 minutes. Ethanol $(100 \%)$ of $200 \mu \mathrm{l}$ was added and vortexed. The supernatant was transferred to a new tube, $500 \mu \mathrm{l}$ buffer AW1 was added to it, and centrifuged at $8000 \mathrm{rpm}$ for 1 minute. The supernatant was taken and $500 \mu \mathrm{l}$ buffer AW2 was added, then centrifuged at $14000 \mathrm{rpm}$ for 3 minutes. The supernatant was taken, added by $200 \mu \mathrm{l}$ of buffer AE, and incubated for 1 minute at room temperature, then centrifuged at $8000 \mathrm{rpm}$ for 1 minute. The resulting DNA was dissolved in $50 \mu \mathrm{l}$ buffer $\mathrm{AE}$ and stored at $-20^{\circ} \mathrm{C}$ for the next process.

DNA Amplification. Amplification of KHV DNA used specified primary TK gene (Bercovier et al. 2005), Forward (F: 5 '- GTA TTA CCT GTA CGA G-3) and Reverse (R: 5'CAC CCA GTA GAT TAT GC -3'). Meanwhile, to qualitatively detect HSP70 expression, specified primary HSP70 was used, which would produce amplification products at $457 \mathrm{bp}$ (Wang et al. 2007), Forward (F: 5'-ATC CTG ATT ACC GAA GAC GG-3 ') and Reverse (R: 5 '-CAT CTG-CTC AAT CTG-3 GCG'). For KHV DNA amplification, the temperature setting was: 1 cycle at $95^{\circ} \mathrm{C}$ for 5 minutes; 35 cycles at $95^{\circ} \mathrm{C}$ for 30 seconds, $52^{\circ} \mathrm{C}$ for 30 seconds, and $72^{\circ} \mathrm{C}$ for 1 minute; and $1 \mathrm{cycle}$ at $72^{\circ} \mathrm{C}$ for 10 minutes. Meanwhile, HSP70 amplification used temperature setting: 1 cycle at $42^{\circ} \mathrm{C}$ for 60 minutes; 1 cycle at $98^{\circ} \mathrm{C}$ for 5 minutes; 1 cycle at $94^{\circ} \mathrm{C}$ for 2 minutes; 30 cycles at $94^{\circ} \mathrm{C}$ for 30 seconds, $58^{\circ} \mathrm{C}$ for 30 seconds and $72^{\circ} \mathrm{C}$ for 30 seconds; 1 cycle at $72^{\circ} \mathrm{C}$ for 10 minutes.

Histopathological Examination. Gills were fixed using 10\% Neutral Buffer Formalin (NBF) for 24 hours. Samples were then processed by embedding and cut with a thickness of $10 \mu \mathrm{m}$. After that, the sections were stained with hematoxylin and eosin (HE) and observed using a microscope at 400x magnification.

\section{RESULTS OF STUDY}

KHV Detection. Detection of KHV was carried out on KHV-infected tilapia and control fish. The test results on gills showed positive KHV signal, amplified at $409 \mathrm{bp}$. The results of detection on tilapia using primary TK gene can be seen in Figure 1.

Meanwhile, based on the results shown in figure 2, it can be seen that two KHVinfected tilapias from different ponds showed a positive signal of HSP70, whereas control tilapia did not show the existence of HSP70. This result indicates that tilapia infected by KHV showed an increased HSP70 expression.

According to histopathological examination, damage to tissue within gills of KHVinfected tilapia (Figure 3) showed that gills experienced fusion of secondary lamellae as a result of hyperplasia, in which the fusion of secondary lamellae in the gills is a characteristic 
symptom of KHV in fish. Furthermore, there were inclusion body and necrosis within the gills. The presence of inclusion body is also a symptom of KHV infection in tissue within gill.

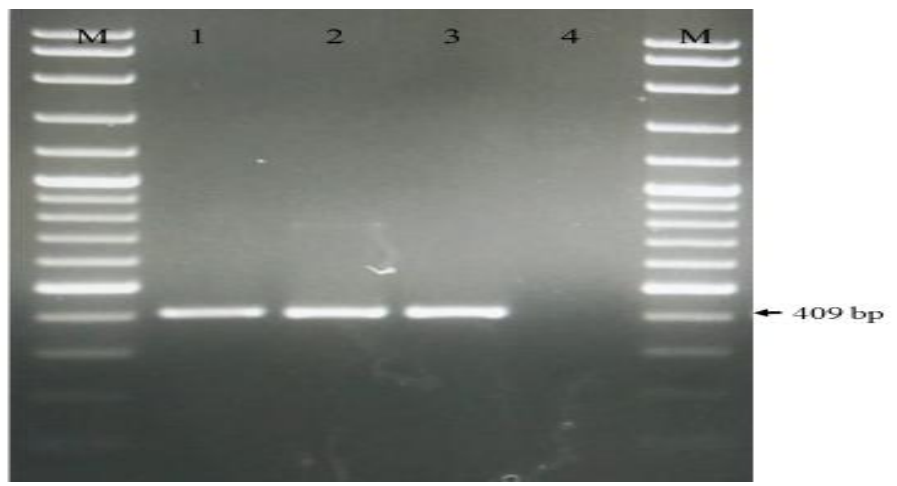

Figure 1 - PCR test result on tilapia using primary TK gene. (M) DNA ladder 100-bp; (1) Positive Control KHV 409 bp; (2) Tilapia of Fishpond 1; (3) Tilapia of Fishpond 2; (4) Tilapia control;

(M) DNA ladder 100-bp

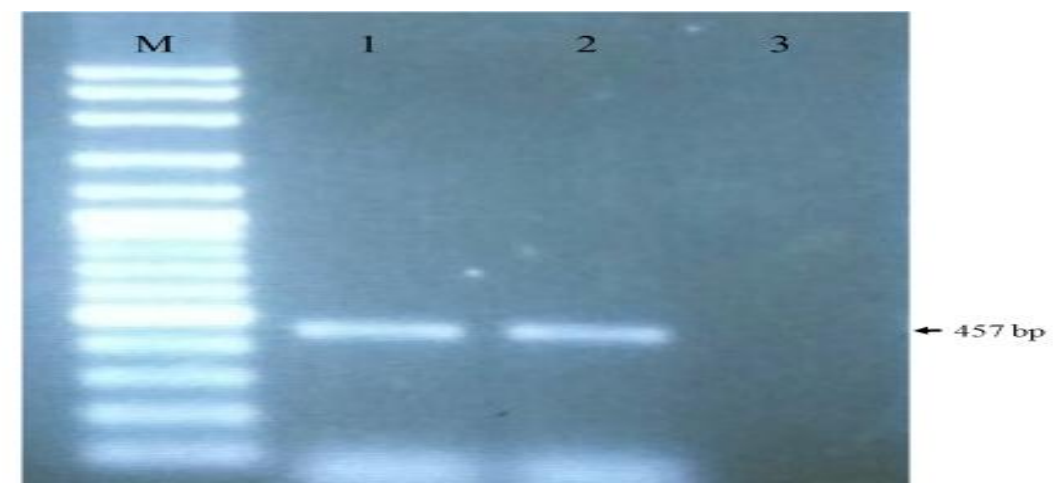

Figure 2 - HSP70 Detection on Tilapia. (M) 100-bp DNA Ladder; (1) Tilapia of Fishpond 1; (2) Tilapia of Fishpond 2; (3) Tilapia Control

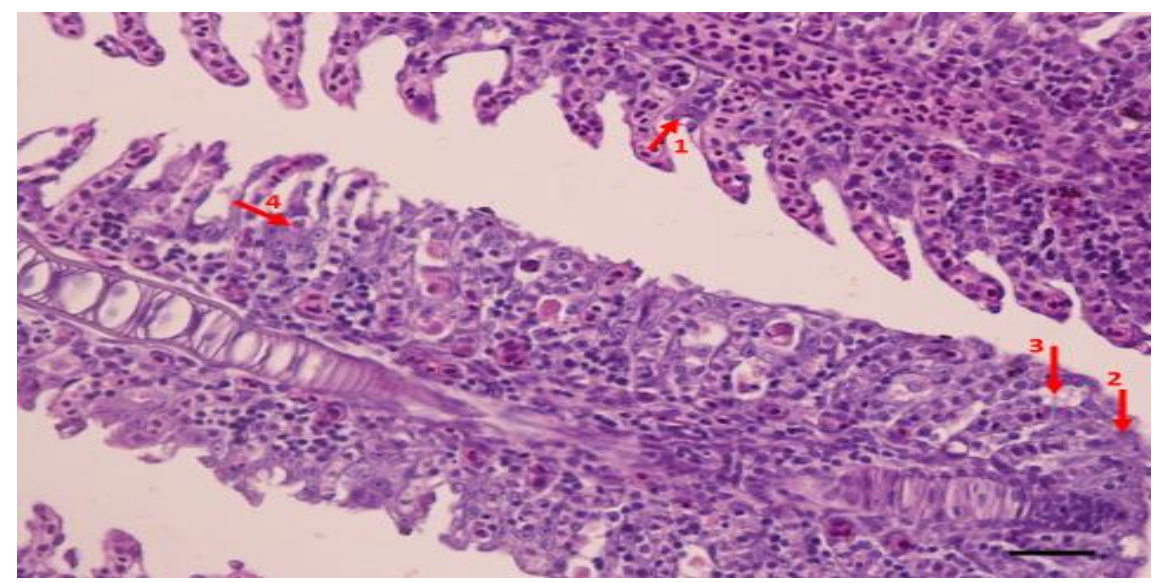

Figure 3 - Histopathology of gills with H\&E staining. (1) Hyperplasia; (2) Inter-lamellar fusion; (3) Necrosis; (4) Inclusion body. Bar $=1 \mu \mathrm{m}$

\section{DISCUSSION OF RESULTS}

The result from observation using molecular assay on the gills of tilapia infected by KHV indicates that there was an increase of HSP70 expression in those organs. This increase was a response to KHV antigens. HSP70 will be induced in response to a stressor that affects the body of the fish. This response indicates that the KHV-infected tilapias 
respond to HSP70 induction, while HSP70 itself is secreted due to Heat Shock Response (HSR). Heat Shock Response (HSR) is a defense response mechanism from cells that experience environmental stress physically (temperature, ultraviolet radiation), biologically (viral, bacterial, nutritional deficiency), or chemically (waste contamination), which will cause a stress response in the form of HSR. If there is severe or lethal stress, it will result in damage or even cell death, whereas if sublethal stress occurs, it will trigger HSR.

Heat shock proteins (HSP) in cells or tissues, under normal conditions, function on protein folding, regulating protein transport, involving in regulating cell cycles and immunity, and also function as molecular chaperones. In abnormal conditions or in conditions triggering stress, HSP will prevent errors in protein folding and prevent protein aggregation that cannot be repaired. In addition, HSP70 can also function in modulating the immune system of the host by acting as pro-inflammatory and anti-inflammatory. Regarding tissue damage caused by KHV infection, namely, necrosis, formation of inclusion body, hyperplasia and interlamellar fusion, the formation of the inclusion body is a sign that viral infection has occurred in the tissue. The inclusion body formed indicates the involvement of HSP70 that acts to aggregate proteins that are not unfolded or misfolded and then to precipitate those proteins in a inclusion body.

In addition, one of the defense responses of fish that experience exposure to pathogens or chemical agents is usually by sticking to secondary lamellae so that fusion is formed. Sano et al. (2004) have explained that fusion occurs because of hyperplasia in the branchial epithelium, which is followed by cell necrosis that is quite clearly noticeable. KHVinfected fish have gill abnormalities, such as hypertrophy, hyperplasia, and fusion on secondary lamellae. Damage to the gill lamella microscopically showed secondary lamellar thickening growth due to increased number and migration of malphigian cells in the primary lamella, causing respiratory area to narrow (Hedrick et al. 2000). Damage to the tissue of tilapia is a response to KHV antigen in the host cell. This response caused HSP of tilapia induced by a stressor to increase, mainly due to exposure or KHV infection. Yanuhar et al. (2015) have stated that cellular responses to an antigen can cause tissue damage.

The function of HSP is to protect tissue from damage caused by viral infections, increased temperature, and inflammation. Inflammation is a complex biological response in blood vessel tissue against dangerous stimuli, one of which is due to pathogenic infection. Other studies have stated that many HSP70 are induced during viral infection. Besides facilitating viral pathogenesis, increased expression of HSP70 induced by cellular stress also relieves stress caused by viral infection (Sullivan \& Pipas, 2001; Neckers \& Tatu, 2008; Roberts et al. 2010). The HSP70 causes KHV-infected tilapia to not experience mortality and be able to survive even though there is tissue damage within the gills.

\section{CONCLUSION}

The results of this study indicate that HSP70 expression was detected in the gills of KHV-infected tilapia, in which the gills are believed to be the main portal entry for KHV into the body of the fish. The presence of HSP70 also presumably intervenes in modulating a series of response mechanisms to prevent damage to the tissue caused by KHV infection.

\section{REFERENCES}

1. Bercovier, H., Fishman, Y., Nahary, R., Sinai, S., Zlotkin, A., Eyngor, M., Gilad, O., Eldar, A. \& R.P. Hedrick. 2005. Cloning of the koi herpesvirus (KHV) gene encoding thymidine kinase and its use for a highly sensitive PCR based diagnosis. BMC Microbiology, 5(13), 1-9.

2. Bergmann, S.M., Sadowski, J., Kiełpiński, M., Bartłomiejczyk, M., Fichtner, D., Riebe, R., Lenk, M. \& J. Kempter, 2010. Susceptibility of koi $\times$ crucian carp and koi $\times$ goldfish hybrids to koi herpesvirus (KHV) and the development of KHV disease (KHVD). Journal of Fish Diseases, 33(3), 267-272. 
3. Bergmann, S.M., \& Cieslak M. 2016. Is There Any Species Specificity in Infections with Aquatic Animal Herpesviruses? The Koi Herpesvirus (KHV): An Alloherpesvirus Model. Fisheries and Aquaculture Journal 7(2), 2-6.

4. Bretzinger, A., Fischer-Scher, T., Oumouma, R., Hoffman, R. \& U. Truyen, 1999. Mass mortalities in koi Cyprinus carpio, associated with gill and skin disease. Bulletin of the European Association of Fish Pathologists, 19(5), 182-185.

5. Diaz-Latoud, C., Diaz, J-J., Fabre-Jonca, N., Kindbeiter, K., Madjar, J-J. \& Andre-Patrick, A. (1997). Herpes simplex virus Us11 protein enhances recovery of protein synthesis and survival in heat shock treated HeLa cells. Cell Stress Chaperones, 2(2), 119-131

6. Haenen, O.L.M., Way, K., Bergmann, S. M. \& E. Ariel, 2004. The emergence of koi herpesvirus and its significance to European aquaculture. Bulletin of the European Association of Fish Pathologists, 24(6), 293-307.

7. Hedrick, R.P., Gilad, O., Yun, S., Spangenberg, J.V., Marty, G.D., Nordhausen, R.W., Kebus, M.J., Bercovier, H. \& A. Eldar, 2000. A herpesvirus associate with mass mortality of juvenile and adult koi, a strain of a common carp. Journal Aquatic Animal Health, $12(1), 44-57$.

8. Hedrick, R.P., Waltzek, T.B. \& T.S. McDowell, 2006. Susceptibility of koi carp, common carp, goldfish, and goldfish $\mathrm{x}$ common carp hybrids to cyprinid herpesvirus-2 and herpesvirus-3. Journal of Aquatic Animal Health, 18(1), 26-34.

9. Garver, K.A, Al-Hussinee, L., Hawley, L.M., Schroeder, T., Edes, S., LePage, V., Contador, E., Russell, S., Lord, S., Stevenson, R. M. W., Souter, B., Wright, E., \& Lumsden, J. S. 2010. Mass mortality associated with koi herpesvirus in wild common carp in Canada. Journal of Wildlife Diseases, 46(4), 1242-1251.

10. Jindal, S. \& Young, R.A. 1992. Vaccinia virus infection induces a stress re- sponse that leads to association of Hsp70 with viral proteins. Journal of Virology, 66, 5357-5362

11. Lin, Y.-R., Hung, H.-C., Leu, J.-H., Wang, H.-C., Kou, G.-H., \& Lo, C.-F. 2011. The Role of Aldehyde Dehydrogenase and Hsp70 in Suppression of White Spot Syndrome Virus Replication at High Temperature. Journal of Virology, 85(7), 3517-3525.

12. Mayer, M.P. 2005. Recruitment of Hsp70 chaperones: A crucial part of viral survival strategies. Reviews of Physiology, Biochemistry and Pharmacology, 153, 1-46.

13. Neckers, L. \& Tatu, U. 2008. Molecular chaperones in pathogen virulence: emerging new targets for therapy. Review of Cell \& Microbe, 4(11 December), 519-527

14. Perelberg, A., Smirnov, M., Hutoran, M. \& A. Diamant, 2003. Epidemiological Description of a New Viral Disease. Israeli Journal of Aquaculture, 55(1), 6758190-6758190.

15. Roberts, R.J., Agius, C., Saliba, P., Bossier \& Sung, Y.Y. 2010. Heat shock protein (chaperones) in fish and shellfish and their potential role in relation to fish health: a review. Journal of Fish Disease, 33(10), 789-801.

16. Sano, M., Ito, T., Kurita, J., Takanori, Y., Watanabe, N., Miwa, S. \& T. lida, 2004. First Detection of Koi Herpesvirus in Cultured Common Carp Cyprinus carpio in Japan. Fish Pathology, 39(3), 165-167.

17. Santoro, M.G. 1994. Heat shock proteins and virus replication: HSP70s as mediators of the antiviral effects of prostaglandins. Experientia, 50, 1039-1047

18. Sullivan, C. S., \& Pipas, J. M. 2001. The virus-chaperone connection. Virology, 287(1), $1-8$.

19. Sunarto, A., Rukyani, A. \& T. Itami, 2005. Indonesian experience on the outbreak of Koi Herpesvirus in Koi and Carp (Cyprinus carpio). Bulletin of Fisheries Research Agency (Japan), (Suppl.2), 15-21.

20. Suprapto, H. \& Y. Kartika, 2012. Monitoring virus by PCR method (Polymerase Chain Reaction) in north coast, east java. Media Jurnal IImiah Perikanan \& Kelautan, 4(1): 1-4.

21. Taukhid, Sunarto, A., Koesharyani, I., Supriyadi, H. \& L. Gardenia. (2004). Strategi pengendalian penyakit koi herpesvirus (KHV) pada ikan mas dan koi. Laboratorium Riset Kesehatan Ikan, Badan Riset Kelautan dan Perikanan, Jakarta. Workshop pengendalian penyakit Koi Herpesvirus (KHV) pada budidaya ikan air tawar. Jakarta 
22. Wahidi, B. R., 2014. Phylogenetic analysis of thymidin kinase gene koi herpesvirus (KHV) in some freshwater fish aquaculture centers in east java. Jurnal Sain Veteriner, 32(1), 130-150.

23. Waltzek, T.B., Kelley, G.O., Stone, D.M., Way, K., Hanson, L., Fukuda, H., Hirono, I., Aoki, T., Davidson, A.J., \& R.P. Hedrick. 2005. Koi herpesvirus represents a third cyprinid herpesvirus (CyHV-3) in the family Herpesviridae. Journal of General Virology, 86(6), 1659-1667.

24. Wang, J., Wei, Y., Li, X., Cao, H., Xu, M., \& Dai, J. 2007. The identification of heat shock protein genes in goldfish (Carassius auratus) and their expression in a complex environment in Gaobeidian Lake, Beijing, China. Comparative Biochemistry and Physiology - Toxicology and Pharmacology, 145(3), 350-362.

25. Yanuhar, U., Christiawan, R., Mahmudi, M., Maizar, A., \& D. Arfiati. 2015. Heat shock protein (Hsp) response within RNA Viral Nervous Necrosis (VNN) that infect of the Humpback Grouper Cromileptes altivelis. 3rd International Conference on Chemical, Agricultural and Medical Sciences (CAMS-2015), Singapore, Dec. 10-11, 9-13.

26. Yuasa, K., Sano M., Kurita J., Ito T. \& T. Lida. 2005. Improvement of a PCR Method with the Sph 1-5 Primer Set for the Detection of Koi Herpesvirus (KHV). Fish Pathology, 40, 37-39. 